\title{
Advances in the Study of the Non-Marine Ostracods in Luanping Basin, Northern Hebei (North China): A Preliminary Result
}

\author{
Zuohuan Qin ${ }^{1,2}$, Dangpeng Xi1 ${ }^{*}$, Benjamin Sames ${ }^{2}$, Qiqing Pang3 ${ }^{3}$ Xiaoqiao Wan1 \\ ${ }^{1}$ State Key Laboratory of Biogeology and Environmental Geology, China University of Geosciences, Beijing, China \\ ${ }^{2}$ Department of Geodynamics and Sedimentology, University of Vienna, Vienna, Austria \\ ${ }^{3}$ Hebei GEO University, Shijiazhuang, China \\ Email: *xdp1121@163.com
}

How to cite this paper: Qin, Z.H., Xi, D.P., Sames, B., Pang, Q.Q. and Wan, X.Q. (2019) Advances in the Study of the Non-Marine Ostracods in Luanping Basin, Northern Hebei (North China): A Preliminary Result. Open Journal of Geology, 9, 601-604.

https://doi.org/10.4236/ojg.2019.910052

Received: August 16, 2019

Accepted: September 20, 2019

Published: September 23, 2019

Copyright (๑) 2019 by author(s) and Scientific Research Publishing Inc. This work is licensed under the Creative Commons Attribution International License (CC BY 4.0).

http://creativecommons.org/licenses/by/4.0/

\begin{abstract}
The Luanping Basin of northern Hebei, North China, is well known for its continuous nonmarine Lower Cretaceous deposits and the preservation of the Jehol Biota. However, there are still some controversies about the stratigraphic correlation in these regions. Here we report some advances on the study of the nonmarine ostracods of Luanping, focusing on its biostratigraphical utility. Preliminary results indicate that the nonmarine ostracods from Luanping Basin consist of 17 genera and around 44 species. The ostracod assemblages of the Dabeigou, Dadianzi and Xiguayuan formations of this Basin can be assigned to the Luanpingella-Ocrocypris-Eoparacypris (Late Valanginian-Early Hauterivian age), Cypridea-Timiriasevia-Daurina (Late Huaterivian-Barremian age) and Cypridea-Limnocypridea-Lycopterocypris (Aptian stage) zones, respectively. This temporary framework can be served as a stratigraphic correlation tool in northern Hebei, as well as contributed to a better understanding of the evolution of the Jehol Biota.
\end{abstract}

\section{Keywords}

Ostracoda, Biostratigraphy, Luanping Basin, Early Cretaceous, Jehol Biota

\section{Introduction}

The Jehol Biota represented a diverse ecosystem in the Cretaceous world, particularly with respect to the high diversity and abundance of fossil species [1]. The study of the Jehol Biota has mainly focused on the Yixian and Jiufotang formations of Western Liaoning, China, which represent the middle and late stage of this biota [2]. The early Jehol Biota and its relevant strata, however, remain to be 
studied further [3]. The Luanping Basin and other basins in the northern Hebei Province, China, preserve abundant fossils of the early Jehol Biota, including non-marine ostracods [2]. Detailed fieldwork on representative sections of the Lower Cretaceous Dabeigou, Dadianzi and Xiguayuan formations of the Luanping Basin have revealed a diverse ostracod fauna with ostracods occurring frequently in the sections and in high abundance [4] [5] [6] [7]. Previous taxonomical and biostratigraphical analyses of the ostracods contribute to the improved age assignment and correlation of respective formations, the correlation with the relevant stage of the Jehol Biota, and on the controversy on the position of the $\mathrm{J}-\mathrm{K}$ boundary in the Luanping basin and adjacent basins [8]. These studies demonstrated the need for more detailed work and thorough taxonomical revision of the ostracod fauna and its biostratigraphical and paleoenvironmental utility.

\section{Materials and Methods}

In an ongoing $\mathrm{PhD}$ project, detailed studies on relevant sections of the Dabeigou (Yushuxia section), Dadianzi (Shangying-Xiaying section), and Dadianzi or Xiguayuan (Liying section) formations of the Luanping Basin are carried out, including high-resolution measuring and sampling for microfossils as well as detailed sedimentological descriptions to establish the lithostratigraphic framework.

\section{Results and Discussion}

Preliminary taxonomic analysis of non-marine ostracods from the Lower Cretaceous interval of Luanping Basin revealed (depending on sections and formations) 7 - 17 genera, including Cypridea, Yumenia, Luanpingella, Pseudoparacypridopsis, Daurina, Yanshanina, Ocrocypris, Eoparacypris, Limnocypridea, Djungarica, Darwinula, Alicenula, Rhinocypris, Timiriasevia, Damonella, Lycopterocypris and Mongolianella, and around 44 species (Detailed discussion will be on another paper). Fieldwork on the Lower Cretaceous interval of the Liying section, the stratigraphical assignment of which either to the Dadianzi or the Xiguayuan Formation is still debated, revealed abundant fossils of gastropods, bivalves, ostracods, spinicaudatans, fishes, shrimps and plants. The ostracod biostratigraphy of the Dabeigou, Dadianzi and Xiguayuan formations can be recognized as the Luanpingella-Ocrocypris-Eoparacypris (Late Valanginian-Early Hauterivian age), Cypridea-Timiriasevia-Daurina (Late Huaterivian-Barremian age) and Cypridea-Limnocypridea-Lycopterocypris (Aptian stage) assemblage zones, respectively. In addition, the ostracod assemblage zone of the Dadianzi Formation can be subdivided into the Cypridea stenolonga, $C$. luanpingensis, $C$. sulcata, and $C$. pangi subzones, which mainly distributed at members 1 - 4 of this formation, respectively. Based on biostratigraphic correlations of the Dadianzi Formation to stratigraphically equivalent formations of adjacent basins, it is concluded that the earliest occurrence of Cypridea-species 
in the northern Hebei-western Liaoning area, North China, is 130 Ma (lowermost Barremian).

\section{Conclusions}

Based on preliminary analysis, 17 genera and around 44 species of the nonmarine ostracods from the Lower Cretaceous interval of Luanping Basin have been recognized.

The ostracod assemblages of the Dabeigou, Dadianzi and Xiguayuan formations of Luanping Basin have been temporarily proposed as the Luanpingella-Ocrocypris-Eoparacypris (Late Valanginian-Early Hauterivian age), Cypridea-Timiriasevia-Daurina (Late Huaterivian-Barremian age) and Cypridea-Limnocypridea-Lycopterocypris (Aptian stage) zones, respectively.

\section{Acknowledgements}

This work was supported by the National Natural Science Foundation of China (41688103, 41790452, 41302008, 41172037), the Program of China Geological Survey (DD20190009, DD20160207), as well as the Austrian Science Fund (FWF) project P 27687-N29 (to BS). Zuohuan Qin was also supported by the Chinese Scholarship Council. The authors have benefitted greatly from the discussions with Yaqiong Wang, Chunlin Sun, Shaowu Niu, Xiaomin Fang and Xuri Wang. We also sincerely thank Yankang Xu, Feng Wei, Xinhua Li, Xuetang Li, Fei Xu, Junjie Zhou, Cong Ding, Zhiqiang Yu, Qian Zhang, Guannan Wang, Anqi Gu, Xin Xiong, Baoxu Wu, Yunqi Ye, Xuejiao Wang, Muhammad Kamran, Jizhe Du, Daben Deng and Jialiang Dai for their help in the field. This is a contribution to UNESCO/IUGS/IGCP 679 project.

\section{Conflicts of Interest}

The authors declare no conflicts of interest regarding the publication of this paper.

\section{References}

[1] Zhou, Z.H. and Wang, Y. (2010) Vertebrate Diversity of the Jehol Biota as Compared with Other Lagerstätten. Science China Earth Sciences, 53, 1894-1907. https://doi.org/10.1007/s11430-010-4094-9

[2] Zhou, Z.H. (2006) Evolutionary Radiation of the Jehol Biota: Chronological and Ecological Perspectives. Geological Journal, 41, 377-393. https://doi.org/10.1002/gj.1045

[3] Tian, S.G., Pang, Q.Q., Niu, S.W., Li, P.X. and Liu, Y.Q. (2004) Terrestrial Jurassic-Cretaceous Stratotype Candidate in Luanping Basin, Northern Hebei. Geological Bulletin of China, 23, 1170-1179.

[4] Yang, R.Q. (1984) Ostracods Assemble of Jurassic-Cretaceous and Its Geological Significance in Hebei. Acta Hebei Geoscience College, 28, 30-46. (In Chinese)

[5] Pang, Q.Q., Zhang, L.X. and Wang, Q. (1984) Paleontological Atlas of North China (three), Micropaleontology Fascicle. Geological Publishing House, Beijing, 59-119. 
(In Chinese)

[6] Pang, Q.Q., Tian, S.G., Li, P.X., Niu, S.W. and Liu, Y.Q. (2006) Ostracod Biostratigraphy of the Dabeigou Formations and Jurassic-Cretaceous Boundary in the Luanping Basin, Northern Hebei. Geological Bulletin of China, 25, 348-356. (In Chinese)

[7] Zhang, L., Yang, Y., Zhang, L., Guo, S., Wang, W., Zheng, Y., Ding, Q. and Cheng, L. (2016) Comparison Research of the Volcanic-Sediment Strata between the Yixian Formation from Western Liaoning and the Dadianzi Formation from Northern Hebei. China University of Geosciences Press, Wuhan.

[8] Qin, Z., Xi, D., Sames, B., Do Carmo, D.A., Wang, X., Xu, Y., Yu, Z., Wei, F., Leite, A.M. and Wan, X. (2018) Ostracods of the Non-Marine Lower Cretaceous Dabeigou Formation at Yushuxia (Luanping Basin, North China): Implications for the Early Jehol Biota Age. Cretaceous Research, 86, 199-218.

https://doi.org/10.1016/j.cretres.2018.03.010 